\title{
26. CLAY MINERALOGY OF THE SHALLOW-WATER DEPOSITS ON ALLISON AND RESOLUTION GUYOTS, SITES 865 AND $866^{1}$
}

\author{
Ivar Murdmaa, ${ }^{2}$ Victor Kurnosov, ${ }^{3}$ and Vera Vasilyeva ${ }^{2}$
}

\begin{abstract}
Using X-ray diffraction data, we studied clay mineral composition and distribution in the shallow-water carbonate sequences drilled during Leg 143 on Allison and Resolution guyots in the Mid-Pacific Mountains. The clay minerals occur in considerable amounts only in the lower parts of the carbonate platform sequences, whereas the upper parts are virtually barren of clay. The disappearance of clay content marks burial of volcanic islands beneath the carbonate platform deposits, which led to removal of the clay mineral sources. We distinguished kaolinite-smectite and hydromica clay-mineral assemblages; the former are derived from basalt weathering products and the latter are formed authigenically in a lagoon environment having restricted water exchange.
\end{abstract}

\section{INTRODUCTION}

Thick carbonate platform sequences drilled during Ocean Drilling Program (ODP) Leg 143 on Allison (Site 865) and Resolution (Site 866) guyots contain clayey interbeds in their lower parts, whereas the upper parts are represented by pure biogenic carbonates almost barren of clay. The purpose of this study was to examine the clay mineralogy and associated authigenic non-clay minerals in the clay-bearing intervals within the carbonate platform sequences.

Lithostratigraphic summaries of Holes 865A (Allison Guyot) and $866 \mathrm{~A}$ (Resolution Guyot) are shown on Figures 1 and 2, respectively (Sager, Winterer, Firth, et al., 1993; Strasser et al., 1995). A late Albian carbonate platform sequence was recovered at Hole 865A (Allison Guyot). It is $630 \mathrm{~m}$ thick and has basaltic sills intruded into its base below Cenozoic pelagic foraminifer-nannofossil ooze (Fig. 1). The sequence is composed of pure, clay-barren rudist/gastropod wackestone (Subunit IIIA) and dasiclad/sponge wackestone-mudstone (Subunit IIIB) in the upper part and of clayey limestones and dolomitic limestones in the lower part (Unit IY, 621-870 meters below seafloor [mbsf]). The lower clay-bearing Unit IY is about $250 \mathrm{~m}$ thick and is composed of bioclastic limestone (wackestone and packstone), dolomitized in the middle part. It is intercalated with numerous laminated dark-colored clayey and organic-rich mudstone interbeds, several centimeters thick, which become more abundant downhole. The clay-bearing unit is interpreted as a lagoonal facies with restricted water exchange and temporary stagnation (Sager, Winterer, Firth, et al., 1993).

On Resolution Guyot (Hole 866A), the carbonate platform sequence is $1600 \mathrm{~m}$ thick and spans an age range from Hauterivian to late Albian (Fig. 2). The upper $400 \mathrm{~m}$ is pure clayless limestone (wackestone with calcrete horizons) of middle to late Albian age (Unit III). It is underlain by an almost 1000 -m-thick Barremian to middle Albian clay-bearing sequence (Units IY through YII, 434-1400 mbsf), which is composed of various lagoonal-peritidal carbonate facies and three oolitic intercalated limestone beds (Strasser et al., 1995). From about $900 \mathrm{mbsf}$, the limestones are partially or totally dolomitized. The sequence contains numerous organic-rich clayey interbeds, each several centimeters thick, and clay-bearing algal laminites, which alternate with pure carbonates (limestones and dolomitized limestones). The lowermost Unit YIII (1400-1620 mbsf) directly overlies basalt

\footnotetext{
${ }^{1}$ Haggerty, J.A., Premoli Silva, I., Rack, F., and McNutt, M.K. (Eds.), 1995. Proc. ODP, Sci. Results, 144: College Station, TX (Ocean Drilling Program).

${ }^{2}$ Institute of Oceanology, Kraikov St. 23, Moscow 117218, Russian Federation.

${ }^{3}$ Geological Institute, Pyshevsky Per. 7, Moscow 109017, Russian Federation.
}

and is composed of dolomitized oolitic-oncoidal grainstone barren of clay (Sager, Winterer, Firth, et al., 1993).

The oolitic grainstone above the basaltic pedestal is interpreted as being deposited in an inner-ramp setting, followed by peritidal and lagoonal facies. The sedimentary record is composed of small sequences, well developed in lagoonal-peritidal settings. Facies evolution indicates cyclic deepening and shallowing of the depositional environment. The clay-rich interbeds and algal mats commonly occur at the sequence boundaries, indicating a transition from regressive to early transgressive environments (Strasser et al., 1995).

Microfaunal assemblages allowed the reconstruction of three types of paleoenvironments: (1) normal salinity open marine, (2) normal salinity lagoonal, and (3) abnormal salinity. The upper middle-late Albian clay-barren interval is characterized by alternating openmarine and lagoonal environments having normal salinity. During the Barremian-Aptian (600-1250 mbsf), abnormal salinity lagoonal environments predominated; however, these were interrupted by short episodes of normal salinity. The Hauterivian oolitic-oncoidal grainstone facies overlies basalts and was deposited predominantly in the open-marine, normal salinity environments that changed to a lagoonal, normal salinity environment in the Barremian.

Both seamounts are presently (and were in the Early Cretaceous) in the central part of the Pacific Ocean, far from any continental terrigenous source. The clay minerals deposited in such localities may be either authigenic or derived from a local source. The only possible local sources were volcanic islands rising above the carbonate platforms after cessation of volcanic activity and before burial beneath the shallow-water carbonates. Thus, clayey intervals within the shallowwater carbonate sequences on both guyots contain information about the burial time of the volcanic islands. They also can provide data on the alteration of igneous rocks on those islands, including climatic conditions of subaerial weathering and possible hydrothermal effects. The main objective of this report was to elucidate such problems using a mineralogical study of samples, collected during Leg 143. We also attempt to interpret some rather peculiar new data on the authigenic mineralogy of the shallow-water deposits, which possibly reflect specific paleoenvironments on the mid-Cretaceous carbonate platforms.

\section{METHODS}

The clay mineralogy and associated authigenic/diagenetic minerals occurring in the shallow-water carbonate sequences at Sites 865 and 866 were investigated primarily using X-ray diffraction (XRD) data obtained during Leg 143 aboard the JOIDES Resolution; the data were supplemented with minor shore-based XRD studies. Scanning electron microscopy (SEM) was used to observe the morphology of 


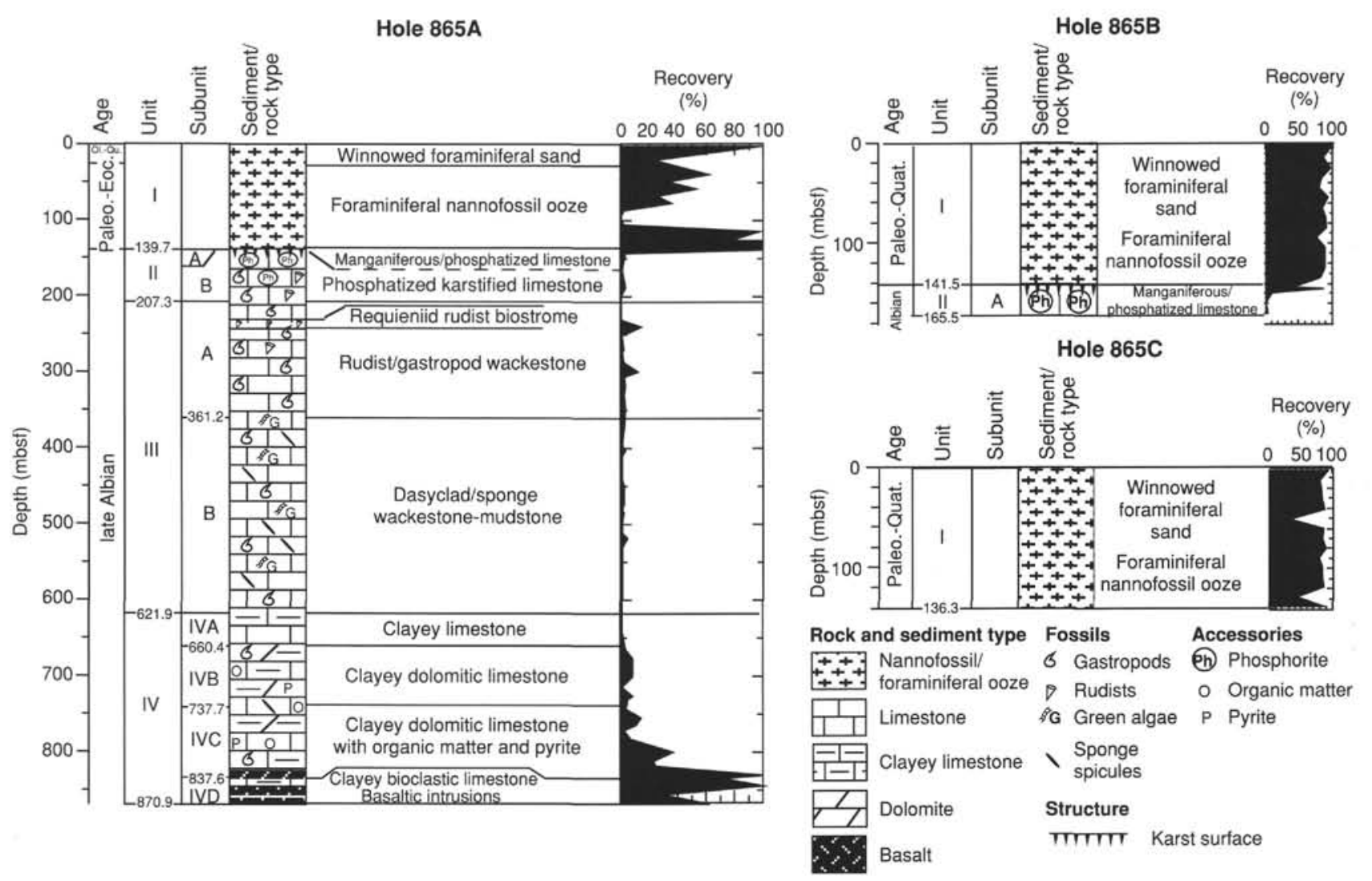

Figure 1. Lithostratigraphic summary of Hole 865A, Allison Guyot (Sager, Winterer, Firth, et al., 1993).

minerals, and thin sections were used to study structural interrelations. Several samples were analyzed by atomic absorption spectroscopy and X-ray fluorescence. The lithology and sedimentary structures of the clayey intervals as well as stratigraphic data are taken from Sager, Winterer, Firth, et al. (1993).

We sampled the entire clay-bearing sequence, sampling only rarely (one per core or less) from pure carbonate intervals and more frequently from clayey intervals as distinguished by visual and smear-slide descriptions. Special attention was paid to discrete, dark, clay-rich (and organic-rich) interbeds and to beds just above or in between basalts.

We split the samples into two parts: one was used for the shipboard XRD analyses and the other for shore-based laboratory analyses. The XRD samples were powdered, and specimens were prepared for major and minor lithologies using either semi-oriented suspension or randomly oriented powder. All air-dried specimens were first analyzed by XRD. Specimens with considerable clay content were then repeatedly analyzed, after they were treated with ethylene-glycol vapors in an exicator and after heating at $550^{\circ} \mathrm{C}$ for $2 \mathrm{hr}$, so as to identify individual clay minerals.

The shipboard XRD measurements were made on a PW 1710 diffractometer with $\mathrm{CuK}$ emission. Step size was $0.01^{\circ} 2$ with an exposition time of $3 \mathrm{~s}$ per step. The scan speed was decelerated in some cases for better resolution of the XRD records.

The shore-based XRD study was conducted on a DRON-3 X-ray diffractometer with $\mathrm{CuK}$ emission, Ni-filter, and slot openings of 0.5 , $1.0,1.0$, and $0.5 \mathrm{~mm}$. Scan speed was $1 \mathrm{~min}$ per $1^{\circ} 2$. Randomly oriented bulk powder specimens and oriented suspension specimens were used. We measured both air-dried specimens and specimens treated with glycerine and heated at $550^{\circ} \mathrm{C}$ for $2 \mathrm{hr}$ before XRD analysis.

We failed to separate clay minerals from carbonates by decantation because the $<2-\mu \mathrm{m}$ "clay fraction" appeared to be even higher in carbonate than the coarse fraction. Only a few samples were treated with $\mathrm{HCl}$ to remove carbonates.

Because clay content is low in most of the samples, we could not apply any of the semiquantitative methods for estimating the relative abundances of individual clay minerals. We therefore denoted the visually evaluated XRD peak heights as trace (T), rare (R), common $(C)$, and abundant (A). "Trace" denotes that the highest peak of a mineral is hardly visible above the background level, indicating only the presence of the mineral. "Abundant" denotes the mineral reflex intensities are comparable with carbonate ones or higher. Intermediate arbitrary ranks of "rare" and "common" represent values in between. Although subjective, such denotation helps to distinguish major changes in the clay mineral assemblages and in associated non-clay minerals.

\section{RESULTS}

The results of XRD analyses, combined with SEM and thinsection data, reveal the following clay minerals: smectite (including Fe-smectite), kaolinite, hydromica (or mixed-layer hydromica with minor K-smectite layers), chlorite, and palygorskite(?). The authigenic non-clay minerals include dolomite (not discussed here), pyrite, gypsum, anhydrite, siderite, K-feldspar(?), apatite, and goethite. An unidentified mineral (zeolite?) having XRD reflections at $3.25 \AA$ and $3.52 \AA$ is also present.

The clay minerals and most of the non-clay minerals are concentrated in centimeter-thick interbeds or in thinner (millimeter-sized) laminae and stylolite surfaces, which are intercalated within thicker pure carbonate layers. The clayey interbeds are commonly enriched in organic matter. The proportion of clay relative to carbonates (calcite or dolomite) in these interbeds is variable, as shown by carbonate content (Site 865, table 6, and Site 866, table 6, in Sager, Winterer, Firth, et al., 1993). The top and bottom boundaries of the dark colored 
Hole 866B
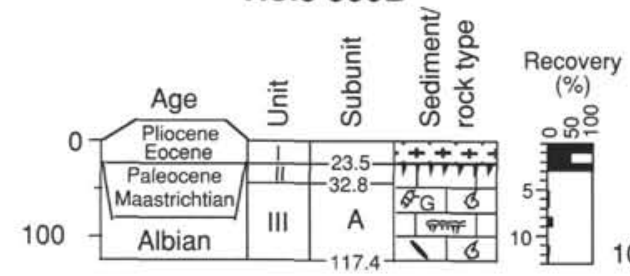

Hole 866A

Rock and sediment type Foraminifer nannofossil ooze \begin{tabular}{|l|l|l}
\hline 1 & L Limestone
\end{tabular} $\square[1]$ Clayey limestone

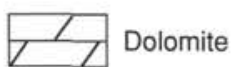

\section{$2 x$ Basalt}

Fossils

6 Gastropods

* Caprinid rudist

${ }_{\mathrm{G}}$ Green algae

(๑) Ooids

$\triangle$ Oncoids

$\triangle$ Orbitolinid foraminifers

- Corals

\ Sponge spicules

Structures

Algal mat
Kr Calcrete
$\mathrm{K}$ Keysiccation cracks
$\mathrm{L}$ Limonitic layers
Accessories
$\mathrm{O}$ Organic matter
D Lithoclasts

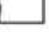
.

\& 要 Recovery (\%)
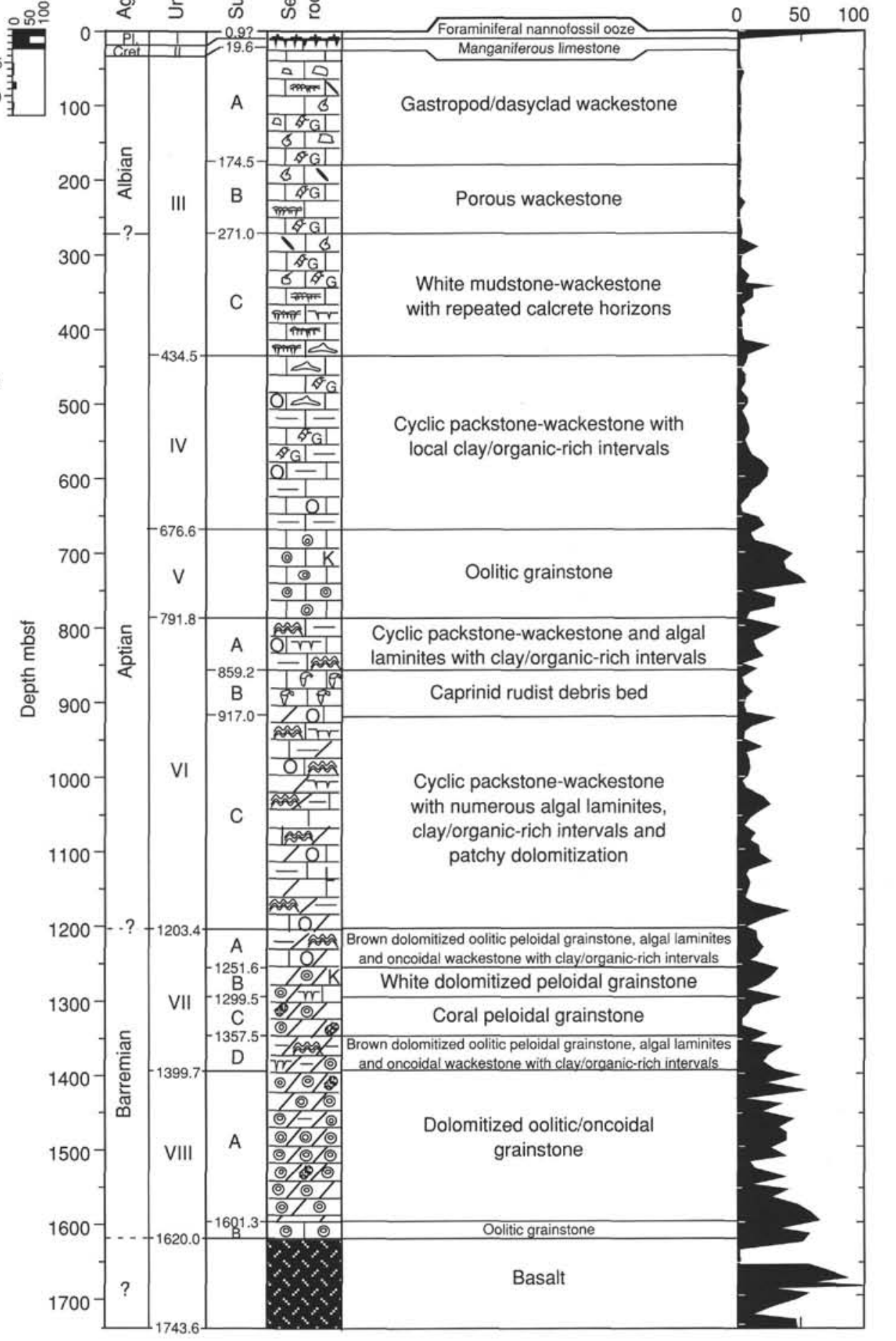

Figure 2. Lithostratigraphic summary of Hole 866A, Resolution Guyot (Sager, Winterer, Firth, et al., 1993).

clayey interbeds are commonly sharp, even in thin section. Thin lamination within the clay interbeds is the most common sedimentary structure; such laminites represent algal mats.

The relative frequency of the clayey interbeds increases downhole at both sites, but their abundance as compared with the carbonate layers is small. The only exception to this occurs just above and in between the basalt sills and flows. The clayey limestones are dominant here.

\section{Hole 865A}

The youngest clay minerals in Hole $865 \mathrm{~A}$ were detected in Sample 143-865A-73R-1, 23-27 cm (670.3 mbsf), in a dark organic-rich interbed in lithostratigraphic Unit IY. Common smectite occurs here along with gypsum, traces of dolomite, and abundant pyrite (Table 1). Within the interval from 749 to $835 \mathrm{mbsf}$, only faint traces of kaolinite 
Table 1. Clay minerals and associated non-clay minerals in the shallow-water carbonate sequence on Allison Guyot, Hole 865A (XRD data).

\begin{tabular}{|c|c|c|c|c|c|c|c|c|c|c|c|}
\hline \multirow{2}{*}{$\begin{array}{l}\text { Core, section. } \\
\text { interval }(\mathrm{cm})\end{array}$} & \multirow{2}{*}{$\begin{array}{l}\text { Depth } \\
\text { (mbsf) }\end{array}$} & \multicolumn{5}{|c|}{ Clay minerals } & \multicolumn{5}{|c|}{ Non-clay minerals } \\
\hline & & $\mathrm{Sm}$ & $\mathrm{Mc}$ & $\mathrm{Ka}$ & $\mathrm{Ch}$ & $\mathrm{Ca}$ & Ap & Gy & Do & Go & Py \\
\hline \multicolumn{12}{|l|}{$14,3-865 \mathrm{~A}-$} \\
\hline $7,3 \mathrm{R}-1.23-27$ & 670.3 & C & & & & A & & C & $\mathrm{R}$ & & A \\
\hline $73 R-1.50-52$ & 670.6 & & & & & A & & & $\hat{R}$ & & \\
\hline $73 \mathrm{R}-1.98-99$ & 671.0 & & & & & $\mathrm{~A}$ & & & $\ddot{R}$ & & \\
\hline $74 \mathrm{R}-1.95-96$ & 680.6 & & & & & A & & & C & & \\
\hline $76 \mathrm{R}-1.1-2$ & 699.1 & & & & & A & & & & & \\
\hline $78 R-1.40-42$ & 718.7 & & & & & A & & & C & & C \\
\hline $78 \mathrm{R}-1.62-66$ & 718.9 & & & & & A & & & C & $\mathrm{T}$ & $\mathrm{R}$ \\
\hline $79 \mathrm{R}-1.2-3$ & 728.1 & & & & & $\hat{A}$ & & & $\mathrm{R}$ & & \\
\hline $80 \mathrm{R}-1.32-35$ & 738.0 & & & & & A & & & A & & $\mathrm{R}$ \\
\hline $80 \mathrm{R}-1,40-42$ & 738.1 & & & & & & & & $\hat{A}$ & $\mathrm{~T}$ & $\mathrm{R}$ \\
\hline $8 \mid R-2.43-44$ & 748.8 & & & $\mathrm{~T}$ & & A & & & A & & \\
\hline $82 R-1.18-19$ & 757.2 & & & & & $\mathrm{R}$ & & & A & & \\
\hline $82 \mathrm{R}-2.2-3$ & 758.0 & & & $\mathrm{~T}$ & & $\hat{A}$ & & & $\hat{\mathrm{C}}$ & & \\
\hline $90 \mathrm{R}-1.105-107$ & 832.8 & & & & & A & & $\mathrm{R}$ & & & \\
\hline $90 \mathrm{R}-2,67-68$ & 833.2 & & & & & A & & & & & $\mathrm{R}$ \\
\hline $90 R-3.9-10$ & 834.1 & & & $\mathrm{~T}$ & & $\hat{A}$ & & & & $\mathrm{~T}$ & $\mathrm{C}$ \\
\hline $90 R-3.33-34$ & 8.34 .3 & & & $\mathrm{R}$ & & A & & & & & $\mathrm{T}$ \\
\hline $90 \mathrm{R}-3.103-104$ & 835.2 & & & & & $\hat{A}$ & & & c & & C \\
\hline $90 \mathrm{R}-3.121-123$ & 835.4 & $\mathrm{~T}$ & & $\mathrm{~T}$ & & $\hat{A}$ & & & $\mathrm{R}$ & & \\
\hline $90 R-4.40-41$ & 835.8 & A & & C & & & & & & & $\mathrm{T}$ \\
\hline $90 R-4,42-43$ & 835.8 & $\hat{A}$ & & $\mathrm{C}$ & $\mathrm{R}$ & & $\mathrm{R}$ & & & & C \\
\hline $90 R-4,52-53$ & 836.1 & c & & $\mathrm{C}$ & & $\mathbf{R}$ & & & $\mathrm{R}$ & & \\
\hline $90 R-4,70-71$ & 836.2 & A & & C & & & & & & & $\mathrm{T}$ \\
\hline $90 \mathrm{R}-4.80-81$ & 836.3 & $\hat{A}$ & & $\mathrm{R}$ & & & & & & & \\
\hline $90 \mathrm{R}-4.110-111$ & 627.3 & C & & $\mathrm{K}$ & & A & & & & & \\
\hline $90 \mathrm{R}-5,60-61$ & 837.3 & C & & R & $\mathrm{R}$ & A & & & & C & \\
\hline $9 \mid R-2,38-39$ & 843.4 & C & & & & $\hat{A}$ & & & & & \\
\hline $9 \mathrm{IR}-3.72-73$ & 844.6 & C & & & & A & & & & & R \\
\hline $9 \mid R-4.25-27$ & 845.6 & $\mathrm{~T}$ & & & & A & & & & & \\
\hline $92 \mathrm{R}-1.68-70$ & 847.9 & $\mathrm{~T}$ & $\mathrm{~T}$ & $\mathrm{~T}$ & $\mathrm{~T}$ & $\hat{A}$ & & & & & \\
\hline $94 \mathrm{R}-3.86-87$ & 866.9 & $\mathrm{R}$ & & & $\mathrm{T}$ & A & & & & & $\mathrm{T}$ \\
\hline $94 \mathrm{R}-3,145-146$ & 867.5 & A & & & & $\mathrm{c}$ & & & & & \\
\hline
\end{tabular}

Notes: Abbreviations for minerals are as follows: $\mathrm{Sm}=$ smectite, $\mathrm{Mc}=$ hydromica. $\mathrm{Ka}=$ kaolenite, $\mathrm{Ch}=$ chlorite, $\mathrm{Ca}=\mathrm{calcite}, \mathrm{Ap}=$ apatite, Gy $=$ gypsum (anhydrite). Do $=$ dolomite. Go $=$ geothite, $\mathrm{Py}=$ pyrite. Abundance indicated as follows: $\mathrm{A}=$ abundant. $\mathrm{C}=\mathrm{common}, \mathrm{R}=$ rare. and $\mathrm{T}=$ trace.

occur in several samples of the dolomitized limestone. Above and in between the basaltic sills, in Cores 143-865A-90R and -91R (835$845 \mathrm{mbsf}$ ), smectite is common, kaolinite ranges from rare to common, and chlorite is absent to rare.

A more detailed study of sediments from the lowermost cores (143-865A-90R through -94R) at 835 to 870.9 mbsf revealed some differences in comparison with the section above, possibly related to the direct influence of the basalts intruded into soft lagoonal deposits. In a clayey limestone sample (143-865A-90R-3, 33-34 cm), the dominant calcite is associated with traces of pyrite and kaolinite as above. Three samples of organic-rich ("lignitic") claystone from Section 143$865 \mathrm{~A}-90 \mathrm{R}-4$ (at $40-41,42-43$, and $70-71 \mathrm{~cm}$ ), just above the uppermost basalt unit, show that Fe-smectite is dominant, kaolinite is common or even abundant, and amorphous phase is abundant. Unidentified reflections at $3.25 \AA$ and $3.52 \AA$ indicate an unknown mineral (zeolite?). A weak reflection at $9.94 \AA$ is evidence of trace amounts hydromica. Potassium feldspar is possibly present in one sample.

Sample 143-865A-92R-1, 68-70 cm, just below the basalt, is clayey limestone composed of dominant calcite with rare smectite and trace amounts of kaolinite (chlorite?) and hydromica. Quartz is probably present and an unidentified reflection at $3.12 \AA$ indicates a significant component of an unidentified mineral. Pyrite was detected in minor amounts.

Samples from Samples 143-865A-94R-3, 86-87 and 145-146 $\mathrm{cm}$, represent clayey limestone and calcareous claystone, respectively, from the sediment layer between two basalt sills. The upper sample $(86-87 \mathrm{~cm})$ is dominated by calcite and has rare smectite. Trace amounts of pyrite, chlorite and K-feldspar(?) are also present. Smectite predominates over calcite in the lower sample (145-146 $\mathrm{cm})$. Weak quartz and feldspar reflections indicate trace amounts of these minerals.

In summary, the clay mineralogy of lithostratigraphic Unit IV at Hole $865 \mathrm{~A}$ is characterized by a kaolinite-ferrismectite assemblage with an increasing abundance of kaolinite in sediments near contacts with basalt sills. Hydromica and chlorite were detected as traces only in the sediments in contact with the basalts. Non-clay authigenic minerals are represented by minor pyrite, traces of potassium(?) feldspar, quartz, and by one or more unidentified minerals (possibly zeolites). These minerals occur only in the lowermost part of Unit IV, just above or in between the basaltic sills. Baudin et al. (1995) also identified berthierine in the Unit IV clayey interbeds.

\section{Hole 866A}

The youngest clay minerals in Hole $866 \mathrm{~A}$ occur as traces of hydromica, kaolinite(?), and chlorite in a dark, pyrite-bearing interbed (Sample 143-866A-44R-CC, 1-2 cm [395.9 mbsf]; Table 2 and Fig. 3). Below, within the interval from 415 to $521 \mathrm{mbsf}$, abundant smectite occurs in most samples of clay-rich interbeds; it is associated with traces of kaolinite, gypsum, anhydrite, and goethite (Fig. 4B).

The clay mineral assemblage changes at about $650 \mathrm{mbsf}$ from predominantly smectite above to glauconite-like hydromica below. Unfortunately, the actual boundary is unknown as a result of poor core recovery and rare sampling. A distinct dark green, 10-cm-thick glauconite (celadonite?) layer occurs at 658.5 mbsf. Sample 143-866A$71 \mathrm{R}-2,76-78 \mathrm{~cm}$, shows abundant mica with traces of calcite, anhydrite, and pyrite (Fig. 4C). Below the glauconite layer, hydromica continues to be the most common clay component down to Section 143-866A-138R-1 (1300 mbsf). However, it occurs only in small amounts, except in Sample 143-866A-91R-1, 27-29 cm (850 mbsf), where it is common. Two samples of dark clay-rich interbeds were analyzed and both had abundant pyrite; one had minor apatite, traces of gypsum, and anhydrite.

The interval between 1300 and 1350 mbsf (Cores 143-866A$139 \mathrm{R}$ through - 143R) is composed of peloidal-oolitic grainstone virtually barren of clay. Downhole from Sample 143-866A-144R-1, 1-2 $\mathrm{cm}$ (1357.5 mbsf), hydromica disappears and smectite is the only clay mineral present, except for weak traces of kaolinite in Sample 143- 
Table 2. Clay minerals and associated non-clay minerals in the shallow-water carbonate sequence on Resolution Guyot, Hole 866A (XRD data).

\begin{tabular}{|c|c|c|c|c|c|c|c|c|c|c|c|}
\hline \multirow{2}{*}{$\begin{array}{l}\text { Core, section, } \\
\text { interval (cm) }\end{array}$} & \multirow{2}{*}{$\begin{array}{l}\text { Depth } \\
\text { (mbsf) }\end{array}$} & \multicolumn{5}{|c|}{ Clay minerals } & \multicolumn{5}{|c|}{ Non-clay minerals } \\
\hline & & Sm & Mc & Ka & $\mathrm{Ch}$ & $\mathrm{Ca}$ & Ap & Gy & Do & Go & Py \\
\hline 143-866A- & & & & & & & & & & & \\
\hline $44 \mathrm{R}-\mathrm{CC}, 1-2$ & 395.91 & & $\mathrm{R}$ & $\mathrm{T}$ & $\mathrm{R}$ & A & & & & & $\mathrm{R}$ \\
\hline $46 \mathrm{R}-1,2-3$ & 415.32 & A & & & $\mathrm{T}$ & A & & $\mathrm{T}$ & $\mathrm{T}$ & T & \\
\hline $46 \mathrm{R}-1,138-139$ & 416.68 & & & & & A & & & & & \\
\hline $48 \mathrm{R}-1,47-48$ & 434.87 & & & & & $\hat{A}$ & & & & & \\
\hline 50R-CC, $39-40$ & 454.09 & A & & T & & $\hat{A}$ & & $\mathrm{~T}$ & $\mathrm{~T}$ & $\mathrm{~T}$ & \\
\hline $5 \mid R-1,3-4$ & 463.43 & & & & & A & & & & & \\
\hline $53 R-1,10-14$ & 482.80 & & & & & A & & & & & \\
\hline $53 \mathrm{R}-1,38-41$ & 483.08 & A & & $\mathrm{T}$ & & A & & $T$ & $\mathrm{~T}$ & $\mathrm{~T}$ & \\
\hline $53 \mathrm{R}-1,71276$ & 483.41 & $\hat{A}$ & & $\mathrm{~T}$ & & A & & $\mathrm{T}$ & & $\mathrm{T}$ & \\
\hline 55R-CC, $40-41$ & 502.30 & $\hat{A}$ & & $\mathrm{~T}$ & & $\hat{A}$ & & $\mathrm{~T}$ & & $T$ & \\
\hline 56R-CC. $19-20$ & 511.79 & A & & $\mathrm{T}$ & & $\ddot{A}$ & & $\mathrm{~T}$ & $\mathrm{R}$ & & \\
\hline 56R-CC, 49-50 & 512.09 & A & & $\mathrm{T}$ & & A & & $\mathrm{T}$ & & T & \\
\hline $57 \mathrm{R}-1,33-35$ & 521.63 & $\hat{A}$ & & $\mathrm{~T}$ & & $\hat{A}$ & & $\mathrm{~T}$ & & $\mathrm{~T}$ & \\
\hline $7 \mid R-2,76-78$ & 658.54 & A & A & & & $\mathrm{R}$ & & & $\mathrm{T}$ & & $\mathrm{R}$ \\
\hline $72 \mathrm{R}-1,59-60$ & 666.79 & $\mathrm{R}$ & $\mathrm{R}$ & & & $\hat{A}$ & & $\mathrm{~T}$ & & & $\mathrm{R}$ \\
\hline $73 \mathrm{R}-1,122-123$ & 677.02 & & & & & $\hat{A}$ & & & & & \\
\hline $74 \mathrm{R}-2,83-84$ & 687.61 & R & $\mathrm{R}$ & & & A & & & & & \\
\hline $75 \mathrm{R}-1,70-71$ & 695.80 & & & & & $\hat{A}$ & & & & T & $\mathrm{R}$ \\
\hline $76 \mathrm{R}-1,136-137$ & 706.06 & & & & & $\hat{A}$ & & & & $T$ & \\
\hline $88 \mathrm{R}-1,141-142$ & 822.31 & $\mathbf{R}$ & $\mathrm{R}$ & & & $\hat{A}$ & & & & & $\mathrm{R}$ \\
\hline $89 \mathrm{R}-1,91-92$ & 831.52 & $\ddot{R}$ & $\mathrm{R}$ & & & A & & & & & $\ddot{R}$ \\
\hline $89 \mathrm{R}-1,98-99$ & 831.58 & R & $\hat{\mathrm{R}}$ & & & A & & & & & $\mathrm{R}$ \\
\hline $9 \mid \mathrm{R}-1,10-11$ & 849.60 & & R & & & A & & & & & $\mathrm{R}$ \\
\hline $91 \mathrm{R}-1,27-28$ & 849.77 & & C & & & & & & & & $\mathrm{R}$ \\
\hline $9 \mid R-1,28-29$ & 849.78 & & C & & & & c & $\mathrm{T}$ & & & \\
\hline $98 \mathrm{R}-1,104-106$ & 918.04 & & & & & A & & $\mathrm{T}$ & $\mathrm{R}$ & & C \\
\hline $115 \mathrm{R}-1,79-80$ & 1078.69 & & $\mathrm{R}$ & & & A & & & $\hat{\mathrm{R}}$ & & \\
\hline $117 \mathrm{R}-1,12-13$ & 1097.22 & $\mathrm{R}$ & & & & A & & $\mathrm{T}$ & A & & $\mathrm{R}$ \\
\hline $129 \mathrm{R}-1,49-50$ & 1213.39 & & $\mathrm{R}$ & & & $\hat{A}$ & & & A & & $\mathbb{R}$ \\
\hline $138 \mathrm{R}-1,25-27$ & 1299.75 & & $\hat{R}$ & & & A & & $\mathrm{T}$ & $\hat{A}$ & $\mathrm{~T}$ & $\mathrm{~T}$ \\
\hline $138 \mathrm{R}-1,27-28$ & 1299.77 & & $\ddot{\mathrm{R}}$ & & & A & & & C & & \\
\hline $144 R-1,1-2$ & 1357.51 & $\mathrm{C}$ & & & & $\hat{\mathrm{R}}$ & $T$ & & C & & A \\
\hline $146 \mathrm{R}-1,135-137$ & 1377.75 & C & & T & & A & & & R & & \\
\hline $169 \mathrm{R}-3,22-23$ & 1602.84 & $\mathrm{R}$ & & & & A & & & & & $\mathrm{R}$ \\
\hline $17 \mid \mathrm{R}-1,53-55$ & 1619.63 & $\hat{R}$ & & & & A & & & A & & $\hat{R}$ \\
\hline $17 \mid R-2,7-9$ & 1619.78 & R & $\mathrm{T}$ & & & $\hat{R}$ & & & $\hat{A}$ & & $\ddot{R}$ \\
\hline $17 \mathrm{IR}-2,51-53$ & 1620.22 & $\hat{R}$ & $\mathrm{~T}$ & & & $\hat{\mathrm{R}}$ & & & $\mathrm{c}$ & & \\
\hline I7IR- $3,40-42$ & 1621.61 & $\mathrm{C}$ & & & & $\mathrm{c}$ & $T$ & & C & & \\
\hline
\end{tabular}

Note: Abbreviations as in Table 1.

866A-146R-1, 135-137 cm (1377.75 mbsf), and of hydromica in two samples from Section 143-866A-171R-2 (1620 mbsf), just above the basaltic basement (Fig. 4).

Three clay mineral zones were indicated by the shipboard and shore-based XRD results (Table 2 ).

\section{Lower Smectite Zone}

A lower smectite zone (1620-1357.5 mbsf; Barremian) is represented by strongly dolomitized oolitic/oncoidal grainstone with clayand organic-rich intervals in the upper and lowermost parts. The zone is separated into two parts by a thick dolomite layer that has no clayey interbeds (Subunit VIII A, 1601-1400 mbsf). The two clay-bearing intervals, below and above the dolomite, may be considered as independent subzones.

The first subzone, just above the basalt (Sections 143-866A-171R1 to $-171 \mathrm{R}-3$ ), contains altered volcaniclastics and is characterized by smectite and trace amounts of hydromica, thus representing alteration (weathering) products of the underlying basalts (Kurnosov et al., this volume). Non-clay authigenic minerals are represented by abundant dolomite and rare or trace amounts of pyrite. Traces of siderite and gypsum were also detected (e.g., Sample 143-866A-171R-3, 40-42 cm). The second subzone (Cores 143-866A-153R to -144R [1440-1358 mbsf]) contains smectite with traces of kaolinite and hydromica. Pyrite is common, and gypsum, anhydrite and quartz(?) occur in rare samples. This subzone has higher kaolinite content than the lower zone.

\section{Hydromica Zone}

The hydromica zone is well defined only in several clay-rich intervals within the 640 -m-thick Barremian to Aptian sequence between 1300 and $658 \mathrm{mbsf}$ (Cores 143-866A-138R to -71R). The location of the boundary with the underlying smectite zone is uncertain because the hydromica appears first in Core 143-866A-138R, and the shallowest occurrence of the smectite-rich clayey interbeds was detected in Sample 143-866A-144R-1, 1-2 cm. The interval in between contains clayless dolomitized peloidal-oolitic grainstone. Though abundant clay-poor intervals occur throughout the hydromica zone, the sparsely distributed clayey interbeds in this zone having glauconite-like hydromica as a single or predominating clay mineral allow the zone to be distinguished from the kaolinite-smectite zones above and below.

Most of the samples analyzed from the hydromica zone contain the glauconite-like hydromica as the dominant or even the single clay mineral. However, within the hydromica zone, we found several interbeds that contain smectite as well as hydromica (Cores 143$866 \mathrm{~A}-115 \mathrm{R},-89 \mathrm{R},-88 \mathrm{R}$, and -74R). Palygorskite(?) is also possibly present in some clayey interbeds in trace amounts.

Non-clay minerals occurring with the hydromica in the clayey interbeds are pyrite, gypsum (with anhydrite), goethite, and potassium feldspar. In some dark-colored, organic-rich interbeds or laminae, gypsum predominates over calcite and hydromica.

An SEM study of several clayey interbeds from the hydromica zone revealed the morphologic and structural interrelations between the minerals. Hydromica displays a distinct authigenic appearance growing on gypsum and pyrite crystals (Plate 1). Pyrite is represented by two morphologies: framboids (Plate 1, Fig. 4) and small cubic crystals (Plate 1, Fig. 5). Both form segregations, possibly replacing organic fragments, or are sparsely distributed in the fine-grained clayey mudstone matrix. Gypsum occurs as euhedral crystals and radiating aggregates (Plate 1, Figs. 5-6). Halite(?)-like crystalline aggregates were observed as fissure infillings in some samples.

The exact identification of the authigenic glauconite-like hydromica required additional examination. The $\mathrm{X}$-ray patterns obtained in 


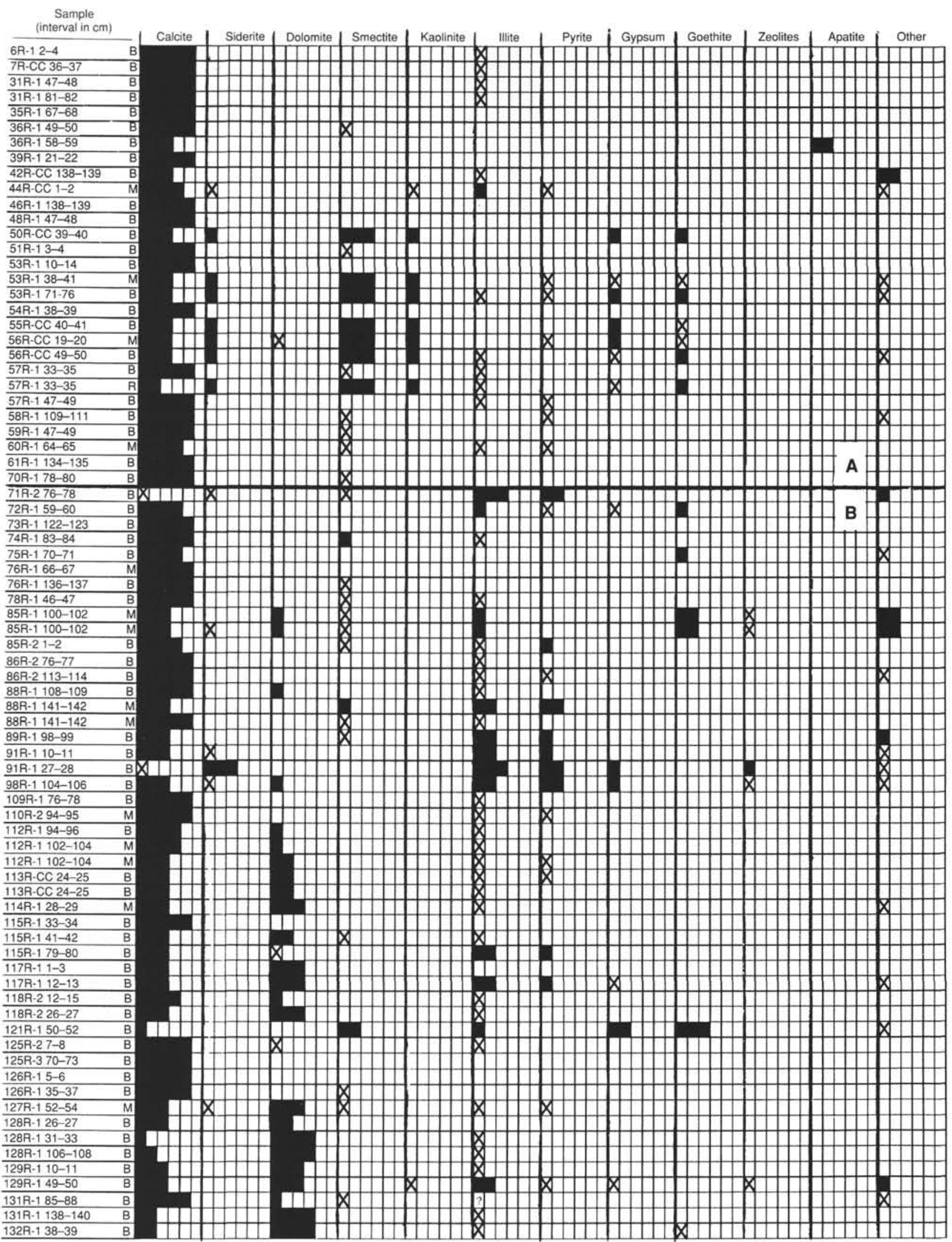

Figure 3. Summary of preliminary shipboard XRD data for the carbonate platform sequence on Resolution Guyot. Relative abundances of minerals are shown in black bar units as follows: 5 units $=$ dominant, 4 units $=$ very abundant, 3 units $=$ abundant, 2 units $=$ common, 1 unit $=$ rare, and $\mathrm{X}=$ trace. Clay-mineral zones: $\mathrm{A}=$ upper smectite $\mathrm{B}=$ hydromica, and $\mathrm{C}=$ lower smectite. 

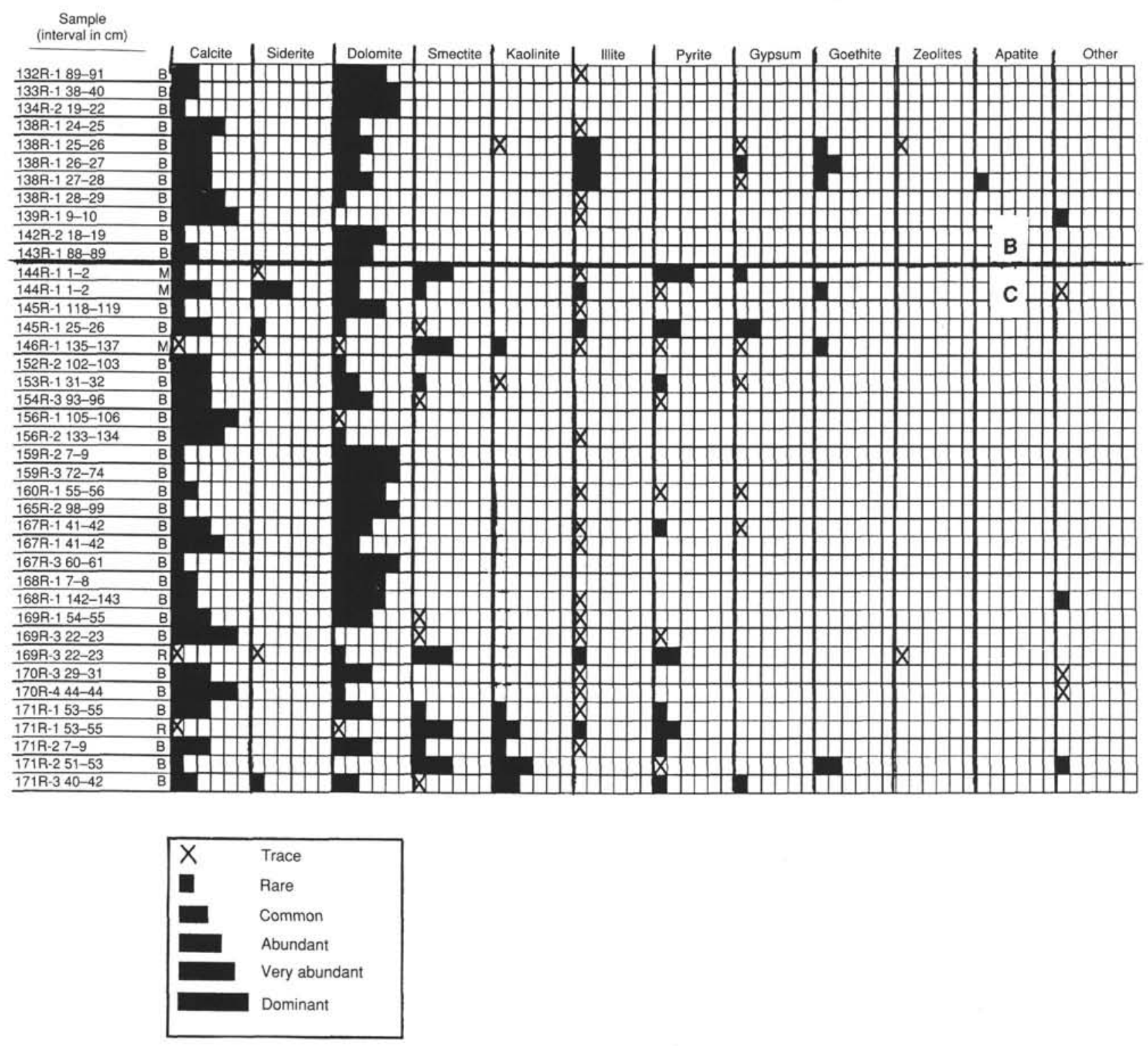

Figure 3 (continued).

the dark green "glauconitic" interbed near the top of hydromica zone (Sample 143-866A-71R-2, 76-78 cm) correspond to those of a glauconite (or celadonite) standard. The double low-angle reflection at 9.94-10.0 $\AA$ and at about $10.8 \AA$, is interpreted as a mixed-layer structure dominated by hydromica with minor K-smectite layers. We obtained similar patterns in other hydromica-rich samples.

The chemical composition of the "glauconitic" interbed averages $\mathrm{SiO}_{2}, 37.59 \% ; \mathrm{Al}_{2} \mathrm{O}_{3}, 14.28 \%$; and $\mathrm{Fe}_{2} \mathrm{O}_{3}, 8.12 \%$ (Röhl et al., 1995), differing from that of typical glauconites in higher $\mathrm{Al}_{2} \mathrm{O}_{3}$ and lower $\mathrm{Fe}_{2} \mathrm{O}_{3}$. Our data from other layers within the hydromica zone (Table 3) also show rather low $\mathrm{Fe}$ relative to $\mathrm{Al}$ (below 1.0). The potassium content ranges from $1.73 \%$ to $2.79 \%$, and the $\mathrm{K} / \mathrm{Al}$ ratio is high enough for both hydromica and $\mathrm{K}$-smectite.

\section{Upper Smectite Zone}

An upper smectite zone was identified in Cores 143-866A-57R through $-46 \mathrm{R}$ (522-415 mbsf), although the poorly sampled interval below, down to at least 560 mbsf (Core 143-866A-60R), probably also contains layers with trace amounts of smectite. Thus, the zone roughly coincides with lithostratigraphic Unit IV represented by cyclic pack- stone-wackestone with rare organic-rich interbeds, but the lower part of Subunit IIIC (mudstone-wackestone with calcretes) is included. Organic-rich clayey interbeds with abundant smectite and traces of kaolinite characterize the clay mineralogy. Non-clay authigenic minerals include gypsum, anhydrite, and goethite, whereas pyrite is absent (Table 2).

Clay minerals were not found in the uppermost part of the shallowwater carbonate sequence (Cores 143-866A-42R to -31R [380-280 mbsf], lithostratigraphic Unit III, Aptian to Albian).

\section{DISCUSSION}

Clay minerals occur in considerable amounts only in the lower parts of the carbonate platform sequences on Allison and Resolution guyots. They are concentrated in discrete clayey interbeds that alternate with pure shallow-water carbonates. Clay accumulation rates exceeding those of carbonate accumulation are necessary to create the concentrated clayey interbeds in lagoonal carbonate deposits. Alternatively, the clay interbeds may have formed during times when carbonate accumulation slowed or when carbonates were dissolved. Subaerial dissolution of limestones is known to form iron-rich soils of terra rossa 

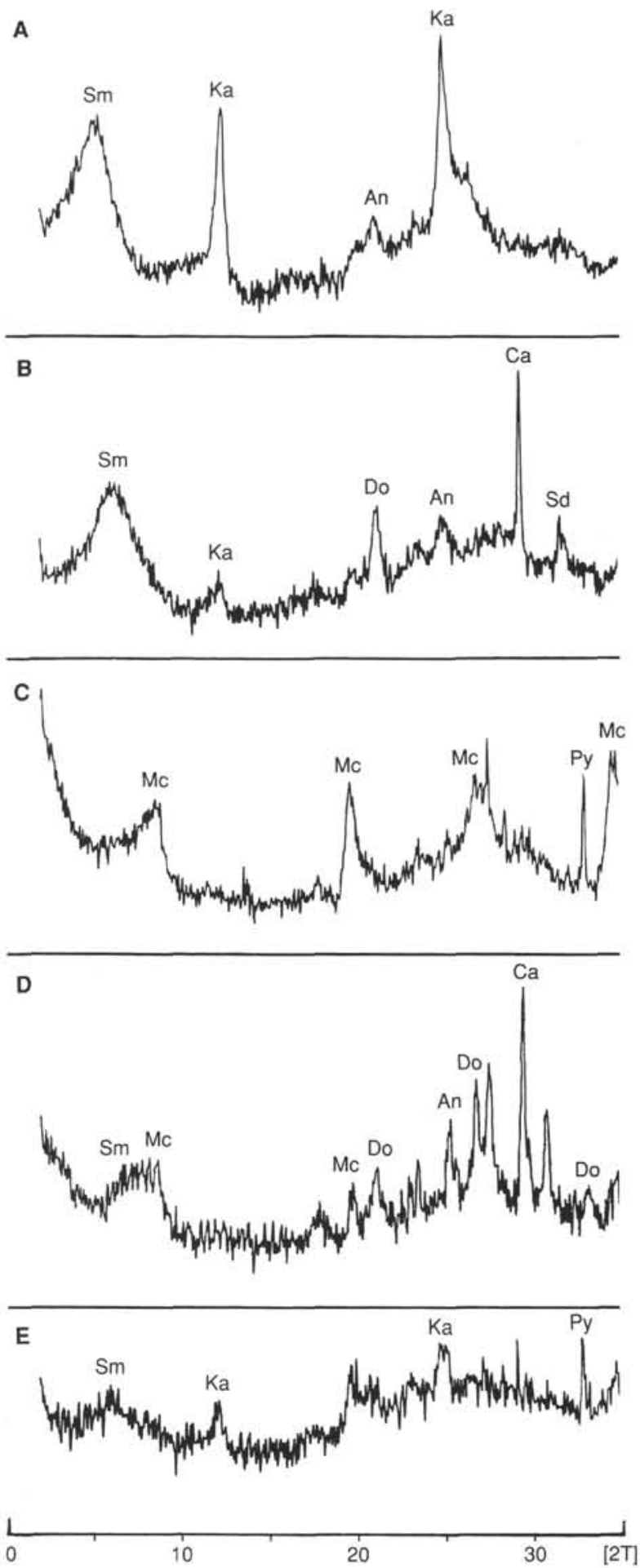

Figure 4. Typical XRD patterns of clay minerals and associated non-clay minerals in selected sequences on Allison (Fig. 4A) and Resolution (Fig. 4B-E) guyots. $\mathrm{Sm}=$ smectite, $\mathrm{Mc}=$ hydromica, $\mathrm{Ka}=$ kaolinite, $\mathrm{Ca}=$ calcite, $\mathrm{Do}=$ dolomite, $\mathrm{Sd}=$ siderite, $\mathrm{Py}=$ pyrite, $\mathrm{Gy}=$ gypsum, and $\mathrm{An}=$ anhydrite. $\mathbf{A}$. Sample 143-866A-90R-4, $42-43 \mathrm{~cm}$, clay fraction. B. Sample 143-866A-56RCC, $49-50 \mathrm{~cm}$, bulk. C. Sample 143-866A-71R-2, 76-78 cm, bulk; dark green "glauconite-like" interbed. D. Sample 143-866A-138R-2, 26-27 cm, bulk; yellowish red "soil" interbed. E. Sample 143-866A-171R-1, 53-55 cm, residue after treating with $\mathrm{HCl}$; clayey limestone just above basalt. type. Red- and black-soil interbeds recovered in the lagoonal sequences (Sager, Winterer, Firth, et al., 1993) may be of such origin. However, extensive submarine dissolution of carbonate sediments, long enough to produce centimeter-thick beds of residual clay from extremely diluted suspended matter of seawater, seems unlikely.

The question of clay sources and supply mechanisms arises. We think volcanic islands that emerged above sea level are the only possible source of detrital clay minerals or of dissolved alumino-silicate constituents for authigenic clay formation on isolated carbonate platforms surrounded by open ocean. The direct sources of clay minerals are subaerial weathering and hydrothermal alteration of the igneous rocks that would be exposed on these islands. If so, clay accumulation in the lagoons would continue until final burial of the subsiding volcanic island beneath the carbonate platform deposits. The burial event is thus marked by the disappearance of clay in the lagoonal sequences. On Allison Guyot, the burial event is fixed at about $670 \mathrm{mbsf}$ in Hole $865 \mathrm{~A}$ (late Albian). On Resolution Guyot, it probably occurs at about $400 \mathrm{mbsf}$ in Hole 866A, also within the late Albian sequence.

We distinguished two major clay-mineral assemblages. The kaolinite-smectite assemblage was distinguished in Hole $865 \mathrm{~A}$ below $670 \mathrm{mbsf}$. In Hole $866 \mathrm{~A}$, it was found in the upper and lower smectite zones. The hydromica assemblage was found in Hole 866A between the lower and upper smectite zones.

The kaolinite-smectite assemblage, commonly dominated by smectite but with a downhole increasing trend of kaolinite (in Hole $865 \mathrm{~A}$ ), is mineralogically similar to the subaerial weathering products of basalts (Kurnosov et al., this volume). Immature lateritic soils formed during subaerial weathering under warm tropical climatic conditions on the volcanic islands most likely serve as the direct source for the clay mineral assemblage deposited in nearby lagoons.

The authigenic glauconite/celadonite-like hydromica, associated with pyrite and gypsum in the middle part of the Barremian-Aptian carbonate platform sequence in Hole 866A, is formed in situ within the organic-rich lagoonal sediments under poorly oxygenated or even anoxic conditions. Dissolved or colloidal alumo-silicates and iron probably are derived from the subaerial weathering of basaltic rocks, although a hydrothermal supply also is possible. The common association with algal mats and organic-rich (sapropelic) sediments, as well as the colloform globular microstructures observed, suggest a possible role of bacterial activity in the authigenic clay formation. Additional study is needed to solve the problem of this unusual clay mineralogy.

It seems important that the hydromica zone with "glauconitic" interbeds coincides stratigraphically with the "abnormal salinity" environment inferred from micropaleontological data and facies reconstruction. The salinity anomaly, reflecting restricted water exchange with the open ocean, is consistent with our speculations about a poorly oxygenated or even anoxic environment in the lagoon, where authigenic glauconite-like hydromica (with minor K-smectite interlayers) was formed with pyrite and gypsum. Increased salinity in semiarid climatic conditions during a relatively low sea-level stand possibly resulted in sulfate precipitation as incipient evaporitic sedimentation. Such conditions were, perhaps, favorable for the hydromica formation, which may also have been stimulated by biochemical activity of bacterial/algal microflora.

Glauconite commonly is thought to be an indicator of open-marine environments with normal seawater salinity. However, in this case, the glauconite-like hydromica probably was formed under conditions of restricted water exchange and abnormal (increased?) salinity. This, along with observed anomalies in composition and morphology of the hydromica described above (as compared with common glauconite), suggests evidence for another mineral of the hydromica group, different from glauconite.

\section{CONCLUSIONS}

Clay minerals occur as clayey interbeds in the lower parts of the carbonate platform sequences on Allison and Resolution guyots. Ab- 
Table 3. Chemical composition of selected clay-rich interbeds from the "hydromica zone" within carbonate-platform sequence on Resolution Guyot, Hole 866A (atomic absorption data, wt \%).

\begin{tabular}{lrrrrrrrr}
\hline $\begin{array}{c}\text { Core, section } \\
\text { interval }(\mathrm{cm})\end{array}$ & $\mathrm{Fe}$ & $\mathrm{Al}$ & $\mathrm{Mn}$ & $\mathrm{Ti}$ & $\mathrm{K}$ & $\mathrm{Fe} / \mathrm{Al}$ & $\mathrm{Al} / \mathrm{Ti}$ & $\mathrm{K} / \mathrm{Al}$ \\
\hline 143-866A- & & & & & & & & \\
121R-1, 50-52 & 13.61 & 8.48 & $<0.001$ & 2.01 & 1.89 & 1.60 & 4.22 & 0.22 \\
$71 \mathrm{R}-2,68-69$ & 6.24 & 8.80 & 0.017 & 0.493 & 2.70 & 0.71 & 17.96 & 0.30 \\
99R-1, 126-127 & 2.53 & 4.03 & 0.123 & 0.281 & 1.71 & 0.63 & 14.34 & 0.43 \\
117R-2, 56-57 & 4.74 & 6.82 & 0.153 & 0.252 & 1.83 & 0.70 & 27.06 & 0.27 \\
120R-1,8-10 & 6.59 & 9.32 & 0.065 & 0.313 & 2.45 & 0.71 & 10.21 & 0.25 \\
\hline
\end{tabular}

sence of the clay interbeds in the upper parts of the carbonate sequences is interpreted as evidence for cessation of the clay supply as a result of final burial of volcanic islands beneath shallow-water carbonates.

Two major clay mineral assemblages are distinguished: (1) the kaolinite-smectite assemblage, which is mineralogically similar to weathering products of alkaline basalts from the same guyots; and (2) the hydromica associated with pyrite and gypsum, which formed authigenically within the organic-rich lagoonal sediments in an environment of restricted water exchange with open ocean leading to a poorly oxygenated regime and, possibly, to increased salinity.

\section{ACKNOWLEDGMENTS}

We are grateful to the reviewers for valuable discussion and critical remarks. We thank the crew of SEDCO/BP 471 and the shipboard technicians for the opportunity to obtain materials for this study. We address special thanks to Mary-Ann Cusimano, who conducted the shipboard XRD measurements for this paper. The study was supported by a Russian Fundamental Science Foundation Grant, "Warm Biosphere."

\section{REFERENCES*}

Baudin, F., Deconinck, J.-F., Sachsenhofer, R.F., Strasser, A., and Arnaud, H., 1995. Organic geochemistry and clay mineralogy of Lower Cretaceous sediments from Allison and Resolution guyots (Sites 865 and 866), MidPacific Mountains. In Winterer, E.L., Sager, W.W., Firth, J.V., and Sinton, J.M. (Eds.), Proc. ODP, Sci. Results, 143: College Station, TX (Ocean Drilling Program), 173-196.

Röhl, U., and Strasser, A., 1995. Diagenetic alteration and geochemical trends of Early Cretacious shallow-water limestones of Allison and Resolution guyots. In Winterer, E.L., Sager, W.W., Firth, J.V., and Sinton, J.M. (Eds.), Proc. ODP, Sci. Results, 143: College Station, TX (Ocean Drilling Program), 197-229.

Sager, W.W., Winterer, E.L., Firth, J.V., et al., 1993. Proc. ODP, Init. Repts., 143: College Station, TX (Ocean Drilling Program).

Strasser, A., Arnaud, H., Baudin, F., and Röhl, U., 1995. Small-scale shallowwater carbonate sequences of Resolution Guyot (Sites 866, 867, and 868). In Winterer, E.L., Sager, W.W., Firth, J.V., and Sinton, J.M. (Eds.), Proc. ODP, Sci. Results, 143: College Station, TX (Ocean Drilling Program), 119-131.

\footnotetext{
Abbreviations for names of organizations and publications in ODP reference lists follow the style given in Chemical Abstracts Service Source Index (published by American Chemical Society).
}

Date of initial receipt: 26 January 1994

Date of acceptance: 15 September 1994

Ms 144SR-069 


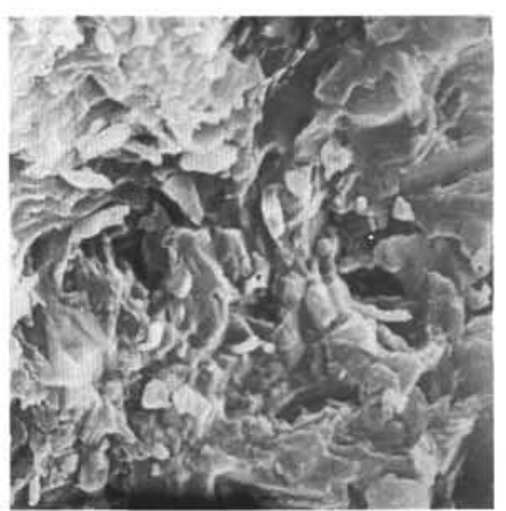

1

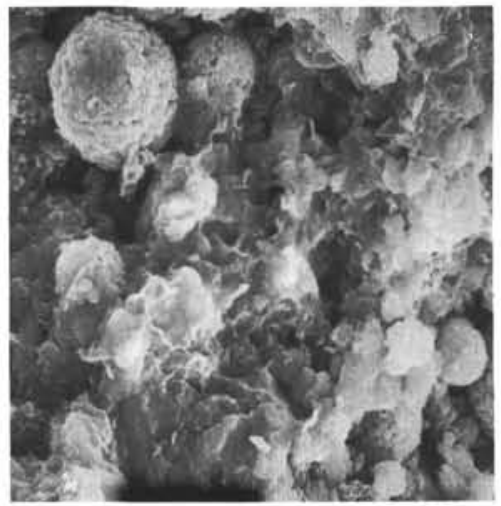

4
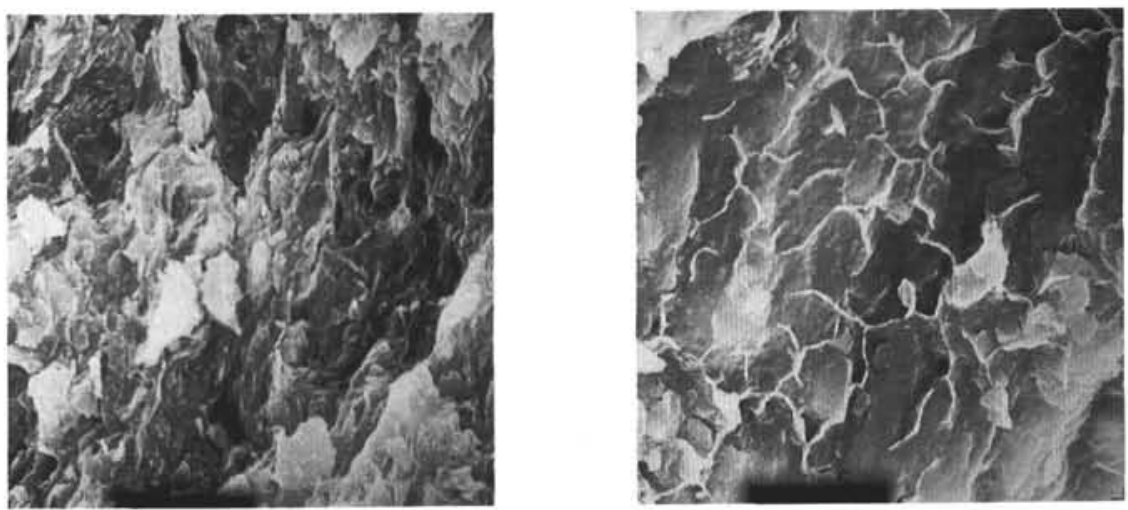

2
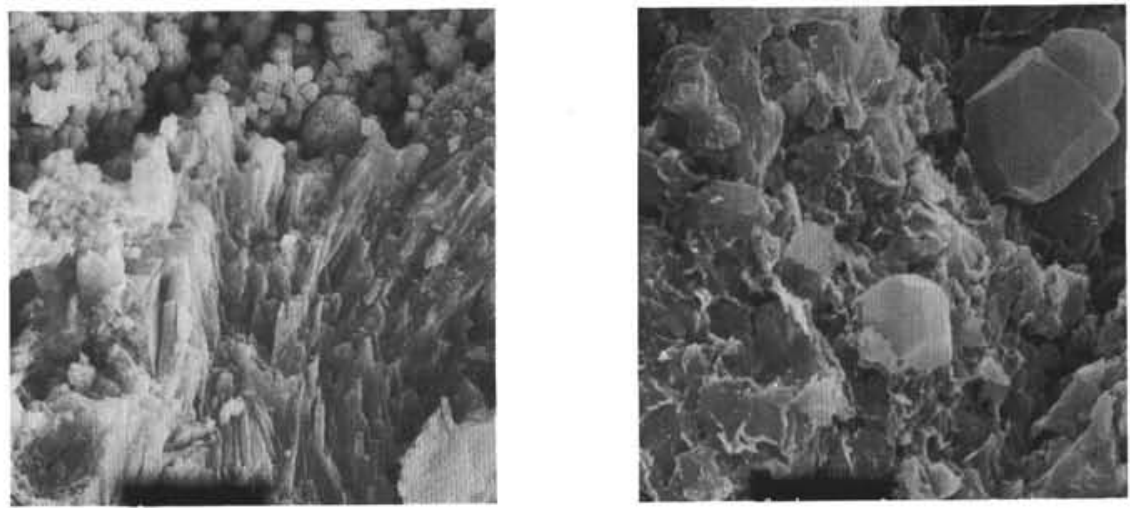

5

6

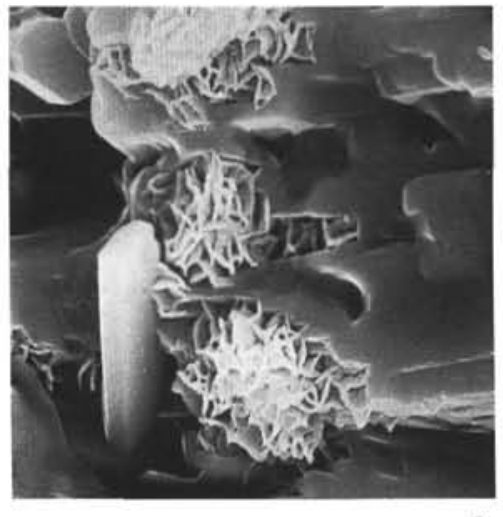

7

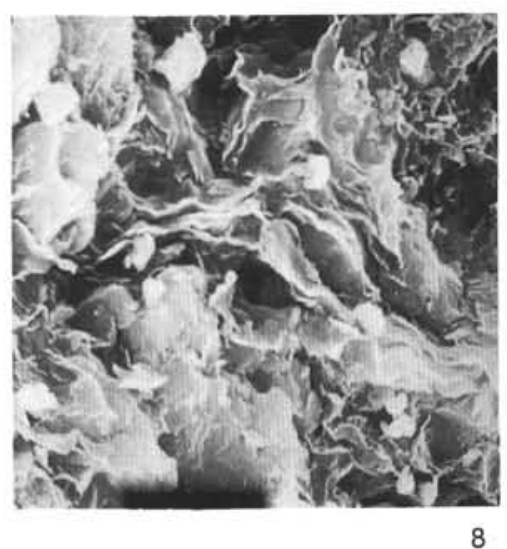

Plate 1. SEM photomicrographs of clay-rich interbeds in shallow-water carbonates from Hole 866A, Resolution Guyot. 1. Authigenic hydromica in clay-rich lamina adjacent to dark green "glauconitic" interbed. Sample 143-866A-7IR-2, 68-69 cm, magnification 3500x. 2. Same sample shown in Figure 1, magnification 2500x. 3. Flakes of hydromica in a clay lamina. XRD showed minor K-smectite interlayers in hydromica. Sample 143-866A-72R-1, 11-13 cm, magnification $1500 \times$. 4. Authigenic hydromica (with K-smectite interlayers) and framboids of pyrite in organic-rich clay lamina. Sample 143-866A-72R-1, 59-60 cm, magnification 1000X. 5. Fine-crystalline cubic pyrite aggregate in contact with gypsum in organic-rich clay lamina. Sample 143-866A-85R-3, $47-49 \mathrm{~cm}$, magnification $3000 \times$. 6. Authigenic hydromica with gypsum crystals in clayey interbed. Sample $143-866 \mathrm{~A}-85 \mathrm{R}-3,47-49 \mathrm{~cm}$, magnification $3000 \times$. 7. Platy-crystalline spheroids of clay mineral(?) with gypsum crystals in organic-rich clayey interbed. Sample 143-866A-88R-1, 56-58 cm, magnification $1500 \times$. 8. Authigenic hydromica in organic-rich clayey interbed. Sample $143-866 \mathrm{~A}-120 \mathrm{R}-1,8-10 \mathrm{~cm}$, magnification $2500 \times$. 